\title{
PEMBERIAN KOMPOS AZOLLA MICROPHYLLA TERHADAP PERTUMBUHAN BIBIT KARET (HEVEA BRASILIENSIS) STUM MATA TIDUR DI PEMBIBITAN
}

\author{
Resi Karlina, Anis Tatik Maryani \\ 1) Fakultas Pertanian, Universitas Jambi \\ Jl. KM 15 Jambi-Muaro Bulian, Kampus Universitas Jambi, 36361 \\ a) email korespondensi: anistatikmaryani25@gmail.com
}

\begin{abstract}
ABSTRAK
Penelitian ini dilaksanakan di Teaching and Research Farm Fakultas Pertanian Universitas Jambi dari bulan April sampai bulan juni 2017 dengan tujuan Mengetahui pengaruh pemberian pupuk kompos Azolla microphylla terhadap pertumbuhan bibit karet (Hevea brasiliensis) stum mata tidur di pembibitan. dan Mengetahui dosis terbaik pupuk kompos Azolla microphylla terhadap pertumbuhan bibit karet (Hevea brasiliensis) stum mata tidur di pembibitan. Penelitian ini menggunakan Rancangan Acak Lengkap (RAL) dengan 5 dosis perlakuan konsentrasi yakni (a0) Tanpa pemberian pupuk kompos azolla microphillya, (a1) $50 \mathrm{~g}$ kompos azolla microphylla/polybeg (a2) $100 \mathrm{~g}$ kompos azolla microphylla/polybeg (a3) $150 \mathrm{~g}$ kompos azolla microphylla/polybeg (a4) $200 \mathrm{~g}$ kompos azolla microphylla/polybeg. Setiap perlakuan terdiri atas 4 ulangan, dan setiap ulangan terdiri atas 4 tanaman dan 3 tanaman diambil sebagai sampel. Hasil penelitian menunjukan bahwa pemberian pupuk kompos Azolla microphylla pada bibit karet (Hevea brasiliensis) stum mata tidur berbeda nyata terhadap parameter yang diamati yakni waktu kuncul mentis,tinggi tunas tanaman, jumlah daun, diameter tunas, jumlah akar, bobot kering akar, dan bobot kering tajuk. Pemberian kompos Azolla Microphylla yang menunjukkan adanya respon tanaman karet stum mata tidur terbaik terdapat pada pemberian kompos Azolla Microphylla dengan dosis $100 \mathrm{~g} /$ polibeg.
\end{abstract}

Kata kunci: Bibit karet stum mata tidur, Kompos Azolla Microphylla, Pembibitan.

\section{PENDAHULUAN}

Tanaman karet (Hevea brasiliensis Muell. Arg.) merupakan salah satu komoditas penting dan strategis bagi Indonesia baik dari sisi ekonomi, sosial, dan lingkungan. Pengembangan perkebunan karet memberikan peranan penting bagi perekonomian nasional, yaitu sebagai sumber devisa, sumber bahan baku industri, sumber pendapatan dan kesejahteraan masyarakat serta pengembangan pusat-pusat pertumbuhan perekonomian dan berperan dalam pelestarian fungsi lingkungan hidup. (Akbar et al., 2013).

Provinsi Jambi pada tahun 2015 memiliki areal tanaman karet seluas 392.259 ha dengan jumlah produksi sebanyak 266.652 ton. Areal perkebunan karet milik rakyat 388.933 ha dengan produksi mencapai 262.578 ton. Berdasarkan luas lahan dan nilai produksi tersebut, produktivitas perkebunan karet rakyat di provinsi Jambi masih relatif rendah yaitu 0,840 ton/ha/tahun dibandingkan dengan produktivitas dari perkebunan karet swasta yaitu 1,223 to/ha/tahun (Direktorat Jenderal Perkebunan, 2014).

Menurut Lasminingsih et al (2012), produktivitas dan kualitas bibit yang rendah menjadi masalah utama perkebunan karet rakyat di Indonesia. Kondisi tersebut dapat dilihat masih adanya petani yang menggunakan bibit cabutan yang berasal dari hutan atau kebun karet tua. Perbaikan utama yang dapat dilakukan untuk mengatasi permasalahan ini adalah menggunakan bibit klon unggul yang berasal dari stum mata tidur. Bibit klon unggul dikembangkan dengan cara okulasi antara batang bawah dan batang atas sehingga menghasilkan sifat-sifat yang lebih unggul dari varietas sejenisnya.

Bibit yang sering digunakan adalah stum mata tidur yang merupakan bibit okulasi yang mata okulasinya belum tumbuh. Keuntungan penggunaan stum mata tidur antara lain waktu penyediaan lebih mudah dan cepat, harga relatif murah serta mudah dalam pengangkutan. Sedangkan kelemahan stum mata tidur karet adalah tingginya persentase kematian stum di lapangan (15\% sampai $20 \%$ ) dan kemungkinan tumbuh tunas palsu. Stum mata tidur yang baik adalah bibit yang mempunyai akar tunggang lurus dengan panjang minimal $25 \mathrm{~cm}$ dan diameter batang 1,2 sampai 3,0 cm sesuai dengan SNI stum mata tidur (Balai Penelitian Sembawa, 2014).

Rekomendasi Badan Litbang Pertanian (2010) salah satu jenis klon unggulan untuk Provinsi Jambi adalah klon PB 260 yang memberikan hasil yang baik dan pertumbuhan yang cepat. Klon PB 260 merupakan klon penghasil lateks, pertumbuhan jagur, produktivitas mencapai 1,5 sampai 2,5 ton ha-1 tahun dan tahan terhadap serangan penyakit Corynospora sp, Colletotrichum sp dan Oidium sp. Menurut Dalimunthe (2004) klon PB 260 lebih tanggap terhadap kondisi lingkungan yang ada seperti relatif lebih tahan pada cekaman air yang berat. 
Pembibitan tanaman karet yang baik dapat juga dilakukan dengan pemberian pupuk yang tepat. Penambahan pupuk yang hanya menitik beratkan pada penggunaan pupuk anorganik semata tidak hanya menyebabkan peningkatan produksi tanaman tetapi juga menimbulkan dampak negatif terhadap tanah karena dapat mengakibatkan terjadinya pencemaran lingkungan. Pemberian pupuk organik dilakukan untuk mengurangi ketergantungan terhadap penggunaan pupuk anorganik (Setyorini, 2005).

Pupuk organik dapat berasal dari bahan -bahan organik seperti kotoran ternak,limbah padat pertanian,tumbuhan air dan lain sebagainya. Salah satu tumbuhan air yang dapat digunakan sebagai pupuk organik adalah Azolla microphylla. Azolla microphylla merupakan tanaman jenis paku air yang hidupnya bersimbiosis dengan Cyanobacteria yang dapat memfiksasi $\mathrm{N}_{2}$. Dengan memanfaatkan Azolla microphylla sebagai pupuk organik yang memiliki kemampuan untuk menyediakan kebutuhan hara bagi tanaman, khususnya kebutuhan akan unsur $\mathrm{N}$, maka kebutuhan $\mathrm{N}$ bagi tanaman dapat terpenuhi tidak hanya dari pupuk anorganik dan pada akhirnya diharapkan dapat mengurangi konsumsi terhadap pupuk anorganik (Rao, 2007).

\section{METODOLOGI PENELITIAN (STYLE: SUB JUDUL)}

Penelitian dilaksanakan di Teaching and Research Farm Fakultas Pertanian Universitas Jambi, Desa Mendalo Indah, Kecamatan Jambi Luar Kota, Kabupaten Muaro Jambi pada ketinggian tempat $\pm 35 \mathrm{~m} / \mathrm{dpl}$. Penelitian dilaksanakan selama 3 bulan dari bulan April sampai bulan Juni 2017.

\section{BAHAN DAN ALAT}

Bahan -bahan yang digunakan dalam penelitian ini adalah bibit karet stum mata tidur klon PB 260, Azolla microphylla, polybag ukuran 20 x $40 \mathrm{~cm}$, air, pupuk kandang sapi $3 \mathrm{~kg}$, kayu, papan, jaringan, dan paranet.

Alat-alat yang digunakan dalam penelitian meliputi meteran, cangkul, parang, gembor, paranet, jaring, penggaris, jangka sorong, timbangan digital, oven, panci, kompor, kamera, buku dan alat tulis.

\section{Rancangan Percobaaan}

Rancangan penelitian ini menggunakan metode Rancangan Acak Lengkap (RAL) satu faktor yaitu terdiri atas 5 macam perlakuan sebagai berikut:

p0 $=$ Pupuk Dasar (sebagai pembanding)

$\mathrm{p} 1=50 \mathrm{~g}$ kompos azolla microphylla / polybeg

p2 $=100 \mathrm{~g}$ kompos azolla microphylla/ polybeg

p3 $=150 \mathrm{~g}$ kompos azolla microphylla / polybeg

p4 = $200 \mathrm{~g}$ kompos azolla microphylla / polybeg

Masing-masing perlakuan diulang sebanyak $5 \mathrm{kali}$, sehingga diperoleh 25 satuan percobaan. Setiap satuan percobaan terdiri dari 4 tanaman sehingga jumlah tanaman seluruhnya adalah 100 tanaman. Setiap satuan percobaan diambil 3 tanaman yang akan dijadikan sebagai tanaman sampel.

\section{Pelaksanaan Penelitian}

Pembuatan pupuk kompos Azolla microphylla dilakukan berdasarkan prosedur atau literature yang ada. Lahan penelitian terlebih dahulu dibersihkan dari gulma yang ada dengan menggunakan cangkul dan parang kemudian tanah diratakan permukaannya. Untuk melindungi bibit dari sinar matahari secara langsung di buat naungan dengan $6 \mathrm{~m} \times 6 \mathrm{~m}$, tinggi naungan $\pm 170 \mathrm{~cm}$. Naungan menggunakan paranet dengan intensitas cahaya $50 \%$.

Persiapan media tanam dilakukan dengan cara mencangkul tanah lapisan atas hingga kedalaman $20 \mathrm{~cm}$ dan di bersihkan dari sampah,kemudian dicampur dengan pupuk kandang sapi,kemudian masukan kedalam polibag dengan ukuran 20 x 40 dan timbang dengan berat $3 \mathrm{~kg}$, diamkan selama seminggu. Kompos ditimbang sesuai dengan perlakuan yang diberikan; 0, 100, 150,200 dan $250 \mathrm{~g} /$ polybag kemudian dicampurkan dengan tanah seberat $3 \mathrm{~kg}$ lalu diberi label. Setelah itu diinkubasi selama seminggu, kemudian baru dilakukan pemindahan bibit karet ke dalam polybag.

Stum mata tidur yang digunakan dipilih yang baik yang berasal dari Balai Pengkajian Teknologi Pertanian (BPTP) Provinsi Jambi. Pemilihan stum mata tidur dilakukan dengan kriteria diameter batang 1,5 - 2,5 cm, akar tunggang lurus dengan panjang $25-30 \mathrm{~cm}$ dan panjang akar lateral $5-10 \mathrm{~cm}$ serta tidak terserang jamur akar putih.

Pada media tanam yang telah disiapkan dibuat lubang dengan tugal kemudian stum mata tidur ditanam sedalam batas leher akar stum. Mata tunas dari stum diletakkan ke arah datangnya sinar matahari lalu tanah dipadatkan.

Penyiraman dilakukan setiap hari atau sesuai dengan kondisi tanam di lapangan. Apabila hujan maka tidak dilakukan penyiraman.

Penyiangan dilakukan secara manual dengan mencabut gulma yang ada di dalam polybag maupun di dalam plot percobaan. Penyiangan dilakukan sesuai kondisi gulma yang ada di lapangan. Apabila terjadi serangan hama pengendaliannya dengan menyemprotkan Decis dengan konsentrasi $2 \mathrm{ml} / \mathrm{L}$ air dan untuk mengendalikan jamur mengunakan Dithane M-45 dengan konsentrasi $2 \mathrm{ml} / \mathrm{L}$

\section{Variabel yang Diamati}

Pengamatan waktu muncul mata tunas diamati dengan menghitung mata tunas yang mentis setiap hari selama 30 hari setelah tanam. Satuan yang digunakan adalah hari setelah tanam (hst).

Pengamatan tinggi tunas hasil okulasi dimulai pada minggu ke-4 setelah tanam dan pengamatan selanjutnya dilakukan setiap 2 minggu sekali sampai minggu ke-12 sehingga terdapat 6 kali pengamatan. Kriteria yang diukur 
adalah tunas yang sudah membentuk batang dan daun. Pengukuran dimulai $\pm 1 \mathrm{~cm}$ dari pangkal tunas okulasi sampai titik tumbuh tertinggi.

Perhitungan jumlah daun dilakukan pada minggu ke-4 setelah tanam dengan selang waktu 2 minggu sekali sampai minggu ke-12. Kriteria daun yang dihitung adalah daun yang telah membuka sempurna dengan satuan helai.

Pengukuran diameter tunas dilakukan pada minggu ke-4 dan diukur pada ketinggian $\pm 1 \mathrm{~cm}$ di atas pangkal tunas okulasi. Pengukuran diameter tunas menggunakan jangka sorong yang dilakukan setiap 2 minggu sekali sampai minggu ke -12 setelah tanam. Satuan yang digunakan adalah $\mathrm{mm}$.

Perhitungan jumlah akar dilakukan pada akhir penelitian dengan cara membongkar tanaman sampel secara hati-hati dan tanaman sampel direndam dalam air sampai leher akar sehingga tanah yang menempel pada akar rontok serta tidak mengganggu kondisi akar. Jumlah akar yang dihitung adalah jumlah akar lateral yang tumbuh pada bagian samping akar tunggang.

Pengamatan bobot kering akar dilakukan diakhir penelitian dengan cara memotong akar tanaman sampel yang tumbuh dari akar tunggang, kemudian akar dimasukkan ke amplop yang telah diberikan label sesuai perlakuan. Selanjutnya akar dikeringkan dalam oven pada suhu 80 0C selama 2 × 24 jam dan ditimbang dengan menggunakan timbangan analitik sampai mendapatkan bobot kering akar yang konstan. Satuan yang digunakan adalah gram.

Pengamatan bobot kering tajuk dilakukan pada akhir penelitian dengan cara memotong tunas tanaman sampel, kemudian tunas dimasukkan ke amplop yang telah diberikan label sesuai perlakuan. Selanjutnya tunas dikeringkan dalam oven pada suhu 80 0C selama 2 x 24 jam dan ditimbang dengan menggunakan timbangan analitik sampai mendapatkan bobot kering tunas yang konstan. Satuan yang digunakan adalah gram.

\section{Analisis Data}

Data pengamatan yang diperoleh dianalisis dengan analisis ragam (uji $\mathrm{F}$ hitung) pada taraf $\alpha=5 \%$ untuk mengetahui adanya pengaruh setiap pemberian kompos dan dilanjutkan dengan uji DMRT (Duncan Multiple Range Test) taraf $\alpha=5$ $\%$.

\section{Data Penunjang}

Data penunjang yang diamati adalah: Analisis tanah awal, analisis kompos Azolla Microphylla, data suhu, curah hujan dan kelembaban nisbi selama percobaan.

\section{HASIL DAN PEMBAHASAN}

\section{Hasil Waktu Muncul Mentis}

Data pengamatan dan hasil analisis ragam menunjukan bahwa pemberian pupuk kompos Azolla microphylla bibit karet stum mata tidur memberikan pengaruh nyata terhadap waktu muncul mentis.

Tabel 1. Waktu muncul mentis bibit karet stum mata tidur dengan pemberian berbagai dosis kompos Azolla microphylla.

\begin{tabular}{cc}
\hline Kompos Azolla Microphylla (ton/ha) & Waktu muncul mentis (hari) \\
\hline 0 & $15,27 \mathrm{ab}$ \\
50 & $18,00 \mathrm{a}$ \\
100 & $10,40 \mathrm{~b}$ \\
150 & $18,27 \mathrm{a}$ \\
200 & $16,73 \mathrm{a}$ \\
\hline
\end{tabular}

Keterangan: Angka-angka dalam kolom yang diikuti huruf yang sama menunjukkan berbeda tidak nyata pada uji jarak berganda Duncan taraf $5 \%$

Tabel 1 menunjukan bahwa hasil uji lanjut memperlihatkan pemberian dosis $100 \mathrm{~g} /$ polybeg berbeda nyata dengan pemberian dosis 200, 150, dan $50 \mathrm{~g} /$ polybeg. Waktu muncul mentis paling cepat terdapat pada dosis $100 \mathrm{~g} / \mathrm{polybeg}$ yaitu rata-rata 10,40 hari, dan paling lambat muncul mentis pada perlakuan pemberian dosis $50 \mathrm{~g} /$ polybeg yaitu ratarata 18 hari.

\section{Tinggi Tunas Hasil Okulasi}

Data pengamatan dan hasil analisis ragam menunjukan bahwa pemberian pupuk kompos Azolla microphylla bibit karet stum mata tidur memberikan pengaruh nyata terhadap tinggi tunas hasil okulasi. Pengaruh perlakuan pupuk kompos Azolla microphylla terhadap pertumbuhan tinggi tunas tanaman bibit karet stum mata tidur umur 4-12 minggu setelah tanam (MST) disajikan pada gambar 1. 


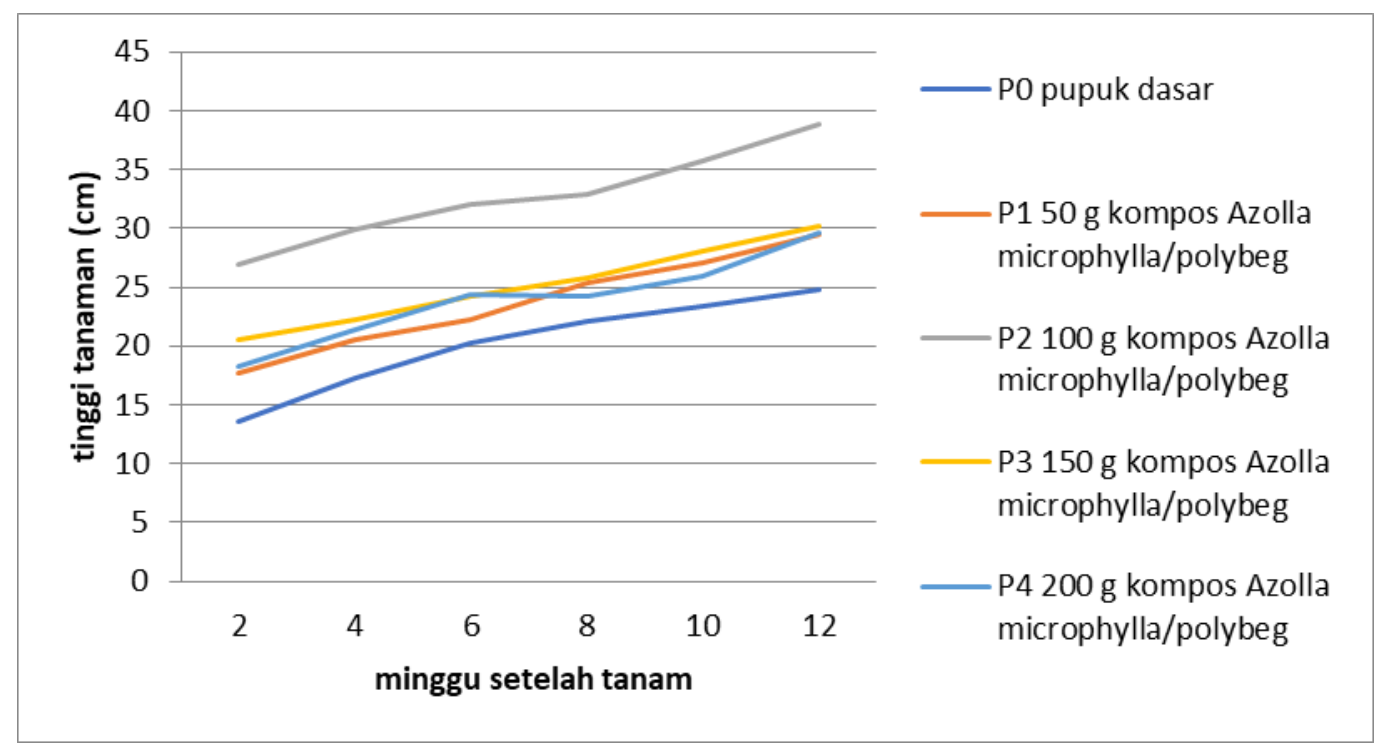

Gambar 1. Tinggi tunas bibit karet pada umur 4 MST sampai dengan 12 MST.

Berdasarkan gambar 1 terlihat bahwa pertumbuhan tinggi tanaman paling pesat terjadi pada umur 2-12 MST. Hal ini diduga karena pada umur 2-6 MST hara yang diperlukan tanaman untuk berfotosintesis telah tersedia melalui kompos yang diberikan sehingga fotosintat yang dihasilkan sebagian besar dimanfaatkan oleh tanaman untuk membentuk organorgan vegetatifnya.

Tabel 2. Tinggi tunas bibit karet dengan pemberian berbagai dosis kompos Azolla microphylla

\begin{tabular}{cccc}
\hline Kompos Azolla Microphylla (ton/ha) & Waktu muncul mentis (hari) \\
\hline 0 & 24,85 & $\mathrm{c}$ & \\
50 & 29,45 & $\mathrm{~b}$ \\
100 & 38,80 & $\mathrm{a}$ \\
150 & $30,18 \mathrm{~b}$ \\
200 & $29,68 \mathrm{~b}$ \\
\hline
\end{tabular}

Keterangan: Angka-angka dalam kolom yang diikuti huruf yang sama menunjukkan berbeda tidak nyata pada uji jarak berganda Duncan taraf $5 \%$

Tabel 2, menunjukan bahwa hasil uji lanjut memperlihatkan pemberian dosis $100 \mathrm{~g} /$ polybeg berbeda nyata dengan pemberian dosis 200, 150, dan $50 \mathrm{~g} /$ polybeg, sedangkan pemberian dosis $50 \mathrm{~g} /$ polybeg tidak berbeda nyata dengan pemberian dosis 150 dan $200 \mathrm{~g} /$ polybeg. pemberian dengan dosis $100 \mathrm{~g} /$ polybeg menunjukkan tinggi tunas yang lebih baik dibandingkan dengan perlakuan lainnya, yakni $38,80 \mathrm{~cm}$. hal ini dikarenakan pada dosis tersebut mampu menyediakan unsur hara $\mathrm{N}$ yang sangat dibutuhkan tanaman untuk pertumbuhan, terutama panjang tunas okulasi, jumlah daun, dan diameter tunas. Pembesaran diameter tunas dipengaruhi oleh ketersediaan unsur kalium. Kalium berperan mempercepat pertumbuhan jaringan meristematik terutama pada batang tanaman, menguatkan batang sehingga tidak mudah rebah dan juga sangat penting dalam proses fotosintesis (Lakitan, 2000).

Unsur $\mathrm{K}$ sangat berperan dalam meningkatkan diameter batang tanaman, khususnya sebagai jaringan yang menghubungkan antara akar dan daun. Batang tanaman berperan dalam menopang bibit dan memperlancar proses translokasi hara dari akar ketajuk.

\section{Jumlah Daun}

Berdasarkan data penelitian dan hasil analisis ragam menunjukan bahwa perlakuan dosis pupuk kompos Azolla microphylla memberikan pengaruh yang nyata terhadap jumlah daun.

Tabel 3. Rata-rata jumlah daun bibit okulasi karet dengan pemberian berbagai dosis kompos Azolla microphylla

\section{Kompos Azolla Microphylla (ton/ha)}

Waktu muncul mentis (hari)

$\begin{array}{ccc}0 & 7,07 & \mathrm{c} \\ 50 & 8,53 & \text { bc }\end{array}$




\begin{tabular}{|c|c|}
\hline 100 & $11,13 \mathrm{a}$ \\
\hline 150 & $10,67 \mathrm{ab}$ \\
\hline 200 & 9,60 \\
\hline
\end{tabular}

Keterangan: Angka-angka dalam kolom yang diikuti huruf yang sama menunjukkan berbeda tidak nyata pada uji jarak berganda Duncan taraf $5 \%$

Tabel 3, dari hasil uji lanjut memperlihatkan bahwa dosis $100 \mathrm{~g} /$ polybeg memiliki jumlah daun terbanyak yaitu 11,13 (helai), tetapi tidak berbeda nyata dengan dosis 150 dan dosis $200 \mathrm{~g} /$ polybeg, namun berbeda nyata dengan dosis $50 \mathrm{~g} /$ polybeg. Sedangkan dosis $50 \mathrm{~g} /$ polybeg memperlihatkan jumlah daun yang paling sedikit yaitu 8,53 (helai), berbeda nyata dengan dosis $100 \mathrm{~g} /$ polybeg.

\section{Diameter Tunas}

Berdasarkan data penelitian dan hasil analisis ragam menunjukan bahwa perlakuan pupuk kompos Azolla microphylla pada berbagai dosis memberikan pengaruh nyata terhadap diameter tunas bibit karet stum mata tidur. Pengaruh konsentrasi pupuk kompos Azolla microphylla pada berbagai dosis memberikan pengaruh nyata terhadap diameter tunas bibit karet stum mata tidur disajikan pada Tabel 4.

Tabel 4. Rata- rata diameter tunas karet stum mata tidur dengan pemberian berbagai dosis kompos Azolla microphylla

\section{Kompos Azolla Microphylla (ton/ha)}

Waktu muncul mentis (hari)

\begin{tabular}{ccc}
\hline 0 & $4,93 \mathrm{~d}$ \\
50 & $6,12 \mathrm{c}$ \\
100 & $7,61 \mathrm{a}$ \\
150 & $6,76 \mathrm{bc}$ \\
200 & $7,04 \mathrm{ab}$
\end{tabular}

Keterangan: Angka-angka dalam kolom yang diikuti huruf yang sama menunjukkan berbeda tidak nyata pada uji jarak berganda Duncan taraf $5 \%$

Tabel 4 memperlihatkan bahwa hasil uji lanjut dosis $100 \mathrm{~g} /$ polybeg berbeda nyata dengan dosis 50 dan dosisi 200 g/polybeg, namun tidak berbeda nyata dengan dosis $150 \mathrm{~g} /$ polybeg. Pertambahan diameter tunas tertinggi pada dosis $100 \mathrm{~g} /$ polybeg sebesar 7,61 cm, sedangkan yang terendah pada dosis $50 \mathrm{~g} /$ polybeg sebesar $6,12 \mathrm{~cm}$

\section{Jumlah Akar}

Berdasarkan data penelitian dan hasil analisis ragam menunjukan bahwa perlakuan pupuk kompos Azolla microphylla pada berbagai dosis memberikan pengaruh nyata terhadap jumlah akar bibit karet stum mata tidur.

Tabel 5. Rata-rata jumlah akar okulasi bibit karet stum mata tidur dengan pemberian berbagai dosis kompos Azolla microphylla.

\begin{tabular}{cc}
\hline Kompos Azolla Microphylla (ton/ha) & Waktu muncul mentis (hari) \\
\hline 0 & $7,53 \mathrm{c}$ \\
100 & $11,13 \mathrm{~b}$ \\
150 & $16,40 \mathrm{a}$ \\
200 & $12,93 \mathrm{~b}$ \\
\hline$a y b$
\end{tabular}

Keterangan: Angka-angka dalam kolom yang diikuti huruf yang sama menunjukkan berbeda tidak nyata pada uji jarak berganda Duncan taraf $5 \%$

Tabel 5 memperlihatkan bahwa hasil uji lanjut dosis $100 \mathrm{~g} /$ polybeg berbeda nyata dengan semua dosis, sementara pemberian pupuk kompos Azolla Microphylla dengan dosis $50 \mathrm{~g} /$ polybeg tidak berbeda nyata dengan dosisi 150 dan dosis $200 \mathrm{~g} /$ polybeg. Jumlah akar yang terbanyak adalah dosis $100 \mathrm{~g} /$ polybeg sebesar 16,40, sedangkan jumlah akar yang terendah adalah dosis $50 \mathrm{~g} /$ polybeg sebesar 11,07.

\section{Bobot Kering Akar}

Berdasarkan data penelitian dan hasil analisis ragam menunjukan bahwa perlakuan konsentrasi pupuk kompos Azolla microphylla memberikan pengaruh yang nyata terhadap bobot kering akar bibit karet stum mata tidur 
Tabel 6. Rata-rata bobot kering akar bibit karet okulasi dengan pemberian berbagai dosis kompos Azolla microphylla (g)

\begin{tabular}{cc}
\hline Kompos Azolla Microphylla (ton/ha) & Waktu muncul mentis (hari) \\
\hline 0 & $1,44 \mathrm{c}$ \\
100 & $1,61 \mathrm{c}$ \\
150 & $3,39 \mathrm{a}$ \\
200 & $2,67 \mathrm{ab}$ \\
\hline
\end{tabular}

Keterangan: Angka-angka dalam kolom yang diikuti huruf yang sama menunjukkan berbeda tidak nyata pada uji jarak berganda Duncan taraf $5 \%$

Tabel 6 hasil dari uji lanjut memperlihatkan bahwa dosis $100 \mathrm{~g} /$ polybeg berbeda nyata dengaan dosis 50 dan dosis $200 \mathrm{~g} /$ polybeg namun tidak berbeda nyata dengan dosis $150 \mathrm{~g} /$ polybeg. Bobot kering akar yang terberat adalah dosis $100 \mathrm{~g} /$ polybeg sebesar 3,39 (g), sedangkan bobot kering akar yang terendah adalah dosis $50 \mathrm{~g} /$ polybeg yaitu sebesar $1,61(\mathrm{~g})$.

\section{Bobot Kering Tajuk}

Berdasarkan data penelitian dan hasil analisis ragam menunjukan bahwa perlakuan konsentrasi pupuk kompos Azolla microphylla memberikan pengaruh yang nyata terhadap bobot kering tajuk bibit karet stum mata tidur. Pengaruh perlakuan dosis pupuk kompos Azolla mivrophylla terhadap bobot kering tajuk bibit karet disajikan pada Tabel 7 .

Tabel 7. Rata-rata bobot kering tajuk bibit karet okulasi dengan pemberian berbagai dosis kompos Azolla microphylla (g)

\begin{tabular}{ccc}
\hline Kompos Azolla Microphylla (ton/ha) & Waktu muncul mentis (hari) \\
\hline 0 & $5,73 \mathrm{c}$ & $6,15 \mathrm{c}$ \\
50 & $10,36 \mathrm{a}$ \\
100 & $7,46 \mathrm{~b}$ \\
200 & $7,17 \mathrm{~b}$
\end{tabular}

Keterangan: Angka-angka dalam kolom yang diikuti huruf yang sama menunjukkan berbeda tidak nyata pada uji jarak berganda Duncan taraf $5 \%$

Tabel 7 hasil dari uji lanjut memperlihatkan bahwa dosis $100 \mathrm{~g} /$ polybeg berbeda nyata dengan semua dosis, sedangkan dosis $200 \mathrm{~g} /$ polybeg tidak berbeda nyata dengaan dosis $150 \mathrm{~g} /$ polybeg, namun berbeda nyata dengan dosis $100 \mathrm{~g} /$ polybeg. Bobot kering tajuk yang terberat adalah dosis $100 \mathrm{~g} /$ polybeg yaitu sebesar 10,36 (g), sedangkan bobot kering tajuk yang terendah adalah $50 \mathrm{~g} /$ polybeg yaitu sebesar 5,73 $(\mathrm{g})$.

\section{KESIMPULAN}

Pemberian beberapa dosis pupuk kompos Azolla microphylla dengan dosis $100 \mathrm{~g} /$ polybeg pada bibit karet asal stum mata tidur dapat meningkatkan pertumbuhan yang lebih baik dibandingkan dengan pemberian perlakuan lainnya, terhadap waktu muncul mentis, tinggi tunas hasil okulasi, jumlah daun, diameter tunas, jumlah akar, bobot kering akar dan bobot kering tajuk. Pemberian pupuk kompos Azolla microphylla pada dosis 100 g/polybeg memberikan pertumbuhan yang terbaik pada semua parameter yang diamati.

\section{SARAN}

Berdasarkan penelitian yang telah dilaksanakan, disarankan menggunakan pupuk kompos Azolla microphylla untuk bibit karet stum mata tidur karena dapat mempercepat pertumbuhan stum mata tidur bibit karet (Hevea brasiliensis). Selain itu, penggunaan pupuk kompos Azolla microphylla lebih ramah lingkungan karena bersifat organik dan bisa mengurangi penggunaan pupuk kimia.

\section{DAFTAR PUSTAKA}

Akbar T, EH Kardhinata, dan S Woelan. 2013. Seleksi Projeni Tanaman Karet (Hevea brasiliensis Muell. Arg.) dari Hasil Persilangan Tahun 2001 - 2003 Sebagai Penghasil Lateks dan Kayu.Agroekoteknologi,1(3):655-667.

Prosiding Penelitian, Seminar Nasional Interdisplin Pascasarjana Universitas Jambi 2020 
Badan Litbang Pertanian. 2010. Potensi Karet Klon Unggul PB 260 dan IRR 39 di Provinsi Jambi. Balai Pengkajian Teknologi Pertanian Jambi.

Balai Penelitian Sembawa. 2014. Rekomendasi Pemupukan Tanaman karet. Balai Penelitian Sembawa, Sembawa.

Boerhendly, I. 2013. Prospek Perbanyakan Bibit Karet Unggul dengan Teknik Okulasi Dini. Jurnal Litbang Pertanian 32, 85-90, (Diunduh 27 Oktober 2015).

Dalimunthe, A. 2004. Tanggap pertumbuhan dan serapan hara bibit karet (Hevea brasiliensis Muell. Arg.) asal stum mata tidur karet terhadap ketersediaan air tanah. Tesis. Program Pasca Sarjana USU. USU e-repository 2008.

Direktorat Jenderal Perkebunan. 2014. Statistik Perkebunan Indonesia 2013-2015 Karet Rubber. Jakarta. Diunduh dari http//ditjenbun .pertanian, go. id tanggal 13 oktober 2015 jam 10.57 wib

Lakitan, S. 2007. Dasar-dasar Fisiologi Tumbuhan. Raja Grafindo Persada. Jakarta.

Lasminingsih, M., Aidi-Daslin, dan S. Woelan.2012.Kinerja Klon Karet Unggul Terkini Pada Skala Pengujian dan Pertanaman Komersial. Prosiding Konfrensi Nasional Karet 2012, 31-37.

Rao, S. 2007. Mikroorganisme Tanah dan Pertumbuhan Tanaman. Penerbit Universitas Indonesia. Jakarta.

Setyorini D. 2005. Pupuk organik tingkatkan produksi pertanian. http://www.pustaka deptan.go.id [13 Februari 2012]. 